\title{
Sosialisasi Pencegahan Penyakit Infeksi Kecacingan Di Wilayah Mataram
}

\author{
Ni Made Amelia Ratnata Dewi ${ }^{{ }^{*}}$, Candra Eka Puspitasari ${ }^{1}$, Nisa Isneni Hanifa $^{1}$ \\ ${ }^{1}$ Program Studi Farmasi, Fakultas Kedokteran, Universitas Mataram, Mataram, Indonesia
}

\section{Article Info}

Received : 17-03-2020

Revised : 31-03-2020

Accepted: 01-04-2020

\begin{abstract}
Helminthiasis is an infection that often attacks children and could result in decreased health, nutrition, intelligence and productivity of the patient. The purpose of this community service activity is to organize a socialization that can improve the understanding of helminthiasis dangers and how to prevent it. The socialization method that used are presentation of the material by the speakers, discussions session and brochures distribution for the audition. The socialization was held in the South Batu Ringgit area. As many as 30 residents participated in this activity. The socialization went well and has produced the expected outcomes. Pre and post assesment to evaluate resident knowledge about helminthiasis were done by written multiple choice quiz. The difference between the pre-test and post-test score was carried out using the Wilcoxon test. Wilcoxon test results showed that there were significant differences between the pre-test and posttest with $\mathrm{p}$ values $=0.03$
\end{abstract}

Keywords: infection, helminthiasis, socialization

Citation: $\quad$ Dewi, N. M. A. R., Puspitasari, C. E., \& Hanifa, N. I. (2020). Sosialisasi pencegahan penyakit infeksi kecacingan di wilayah Mataram. INDRA Jurnal Pengabdian kepada Masyarakat, 1(1), 1-4.

\section{Pendahuluan}

Infeksi akibat cacing (helminthiasis) merupakan salah satu infeksi yang sering menyerang anak-anak dengan tingkat ekonomi yang rendah terutama pada negara-negara berkembang seperti Asia, Afrika dan Amerika latin (Weatherhead \& Hotez, 2015). Sekitar lebih dari 1.5 milyar orang atau sekitar $24 \%$ dari jumlah populasi dunia pernah mengalami infeksi kecacingan. Infeksi terjadi di negara-negara tropis maupun subtropis, dengan jumlah terbanyak terdapat pada negara sub-Sahara Afrika, Amerika, China dan Asia Timur (WHO, 2003). Infeksi kecacingan tergolong penyakit kurang diperhatikan, dimana infeksi ini tidak menyebabkan gejala klinis yang jelas, sifatnya kronis serta dampak yang ditimbulkannya baru terlihat dalam jangka panjang (Kurniawan, 2010). Cacingan mempengaruhi pemasukan (intake), pencernaan (digestif), penyerapan (absorbsi) dan metabolisme makanan. Infeksi cacing dapat menimbulkan kerugian zat gizi berupa kekurangan kalori dan protein serta kehilangan darah. Selain dapat menghambat perkembangan fisik, kecerdasan dan produktivitas kerja, infeksi cacing juga dapat menurunkan daya tahan tubuh sehingga mudah terkena penyakit lainnya (Kemenkes RI, 2006).

Di Indonesia masih banyak penyakit yang merupakan masalah kesehatan, salah satu diantaranya ialah cacing perut yang ditularkan melalui tanah atau disebut soil-transmitted helminth yakni cacing gelang (Ascaris lumbricoides), cacing cambuk (Trichuris trichiura), dan cacing tambang (Necator americanus dan Ancylostoma duodenale) (Sutanto, Ismid, Sjarifuddin, \& Sungkar, 2008). Prevalensi kecacingan di Indonesia pada umumnya masih sangat tinggi, terutama pada golongan penduduk yang kurang mampu, dengan sanitasi yang buruk. Prevalensi Kecacingan bervariasi antara 2,5\%-62\% (Kemenkes RI, 2017). Provinsi Nusa Tenggara Barat merupakan salah satu provinsi di 
Indonesia dengan tingkat kejadian kecacingan yang tinggi. Tingginya prevalensi kejadian infeksi cacing gelang ditemukan sangat tinggi pada dua sekolah (78,5\% dan $72,6 \%)$, dan infeksi cacing cambuk prevalensinya adalah $63,95 \%$ dan 60,0\% (Ismid, 1999). Di Lombok Timur prevalensi tinggi angka kejadian kecacingan juga ditemukan di dua sekolah yaitu $73,45 \%$ dan $96,57 \%$ untuk infeksi cacing gelang serta $69,03 \%$ dan $79,43 \%$ untuk infeksi cacing cambuk (Margono, 2003).

Pengendalian penyakit kecacingan sangat penting dilakukan untuk menurunkan prevalensi penyakit ini agar dapat meningkatkan mutu sumber daya manusia dalam mewujudkan Indonesia yang sehat. Cara utama dalam pengendalian penyakit kecacingan adalah dengan memutus mata rantai lingkungan hidup cacing yang bisa dilakukan pada tingkatan cacing di lingkungan, tubuh manusia, sosial dan budaya (Anwar, 2014). Upaya dalam mengatasi kejadian penyakit kecacingan, tidak cukup dengan melakukan pengobatan saja. Namun, ada faktor-faktor lain yang berperan dalam menunjang penyakit ini, yaitu keadaan sosial ekonomi masyarakat yang rendah, serta faktor kebersihan lingkungan masyarakat (Eryani, Fitriangga, \& Kahtan, 2015).

Berdasarkan latar belakang tersebut, perlu dilakukan sosialisasi untuk memberikan informasi kepada masyarakat tentang bahaya dan cara mencegah penyakit kecacingan sehingga dapat terwujud peningkatan derajat kesehatan masyarakat.

\section{Metode}

Pelaksanaan kegiatan pengabdian dilakukan dengan berkolaborasi bersama Himpunan Mahasiswa Farmasi Universitas Mataram serta Puskesmas Tanjung Karang, Mataram. Puskesmas memiliki program pencegahan kecacingan yang rutin dilakukan bulan Agustus.

Metode pelaksanaaan kegiatan dibagi dalam tahapan berikut:

1. Pre-test untuk mengetahui tingkat pengetahuan warga terkait infeksi kecacingan. Pre-test yang diberikan berupa soal pilihan ganda terkait kecacingan

2. Sosialisasi tentang bahaya dan cara mencegah penyakit infeksi kecacingan dengan menghadirkan apoteker sebagai narasumber

3. Diskusi dan tanya jawab mengenai bahaya dan cara mencegah infeksi kecacingan

4. Pembagian brosur tentang penyakit kecacingan dan cara pencegahannya

5. Post-test dilakukan untuk mengetahui tingkat pemahaman warga setelah sosialisasi dengan memberikan soal pilihan ganda.
Data pre-test dan post-test diolah menggunakan statistik menggunakan uji beda berupa t-test atau uji Wilcoxon, dimana nilai $\mathrm{p}<0.05$ dianggap signifikan.

\section{Hasil dan Pembahasan}

Kegiatan dilaksanakan pada tanggal 21 Agustus 2019 di daerah Batu Ringgit Selatan. Kegiatan sosialisasi bekerja sama dengan bagian promosi kesehatan Puskesmas Tanjung Karang. Sosialisasi dilaksanakan di Pusat Kegiatan Belajar Masyarakat Istiqomah di daerah Batu Ringgit. Sebelum pelaksanaan kegiatan, panitia berkoordinasi dengan kader di desa setempat untuk kelancaran kegiatan ini. Pelaksanaan kegiatan berlangsung selama 3 jam dari pukul 08.00 hingga 11.00. Peserta sosialisasi adalah para ibu dari anak-anak PAUD Istiqomah. Peserta kegiatan sosialisasi berjumlah 30 orang.

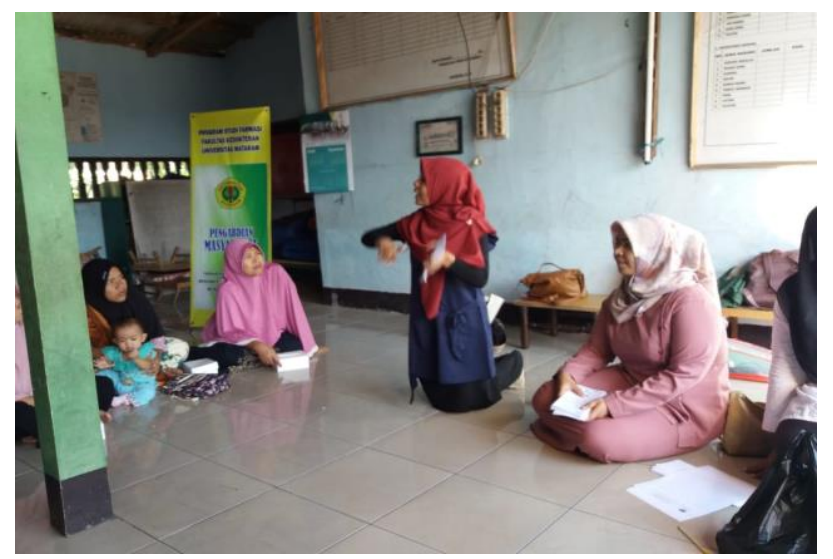

Gambar 1. Kegiatan Sosialisasi Penyakit Kecacingan

Alur kegiatan meliputi pendaftaran peserta sosialisasi, dilanjutkan dengan pre-test kemudian dilakukan pemaparan materi sosialisasi yaitu "Pencegahan Penyakit Infeksi Kecacingan". Setelah pemaparan materi, dilakukan sesi diskusi tanya jawab dan diakhiri dengan post-test. Warga sangat antusias dengan acara sosialisasi ini. Hal ini terbukti dengan kedatangan warga semenjak pagi hari yang memenuhi tempat kegiatan meskipun kegiatan baru dimulai pukul 08.30. Sebelum kegiatan sosialisasi dilaksanakan pre-test untuk mengetahui tingkat pengetahuan dari peserta terkait infeksi kecacingan. Soal pre-test merupakan soal pilihan ganda berjumlah 5 soal yang berisi pertanyaan terkait kecacingan. Pada saat pre-test didapatkan rerata hasil nilainya adalah sebesar 5,48; dimana nilai maksimal adalah 10 . Setelah dilaksanakan pre-test dilanjutkan dengan sosialisasi terkait pencegahan kecacingan serta tanya jawab. Materi sosialisasi berisi tentang pengertian penyakit kecacingan, jenis cacing yang sering menginfeksi, cara mencegah penyakit kecacingan dan penularan, gejala kecacingan serta terapi dan pengobatan jika mengalami 
kecacingan. Materi sosialisasi dirangkum di dalam leaflet yang dibagikan kepada masing-masing peserta. Peserta sangat antusias dalam menanyakan hal-hal yang terkait dengan penyakit kecacingan.

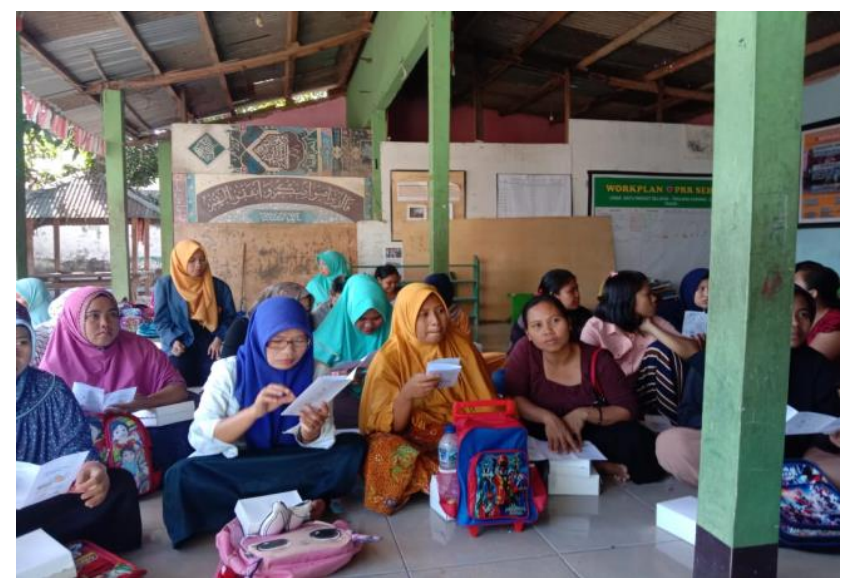

Gambar 2. Post-test Setelah Sosialisasi

Acara diskusi kemudian dilanjutkan kembali dengan post-test. Post-test dilakukan untuk mengevaluasi hasil dari sosialisasi yang telah dilaksanakan. Soal post-test yang digunakan sama dengan soal pre-test. Nilai rerata setelah dilakukan post-test mengalami peningkatan yaitu sebesar 7,69.

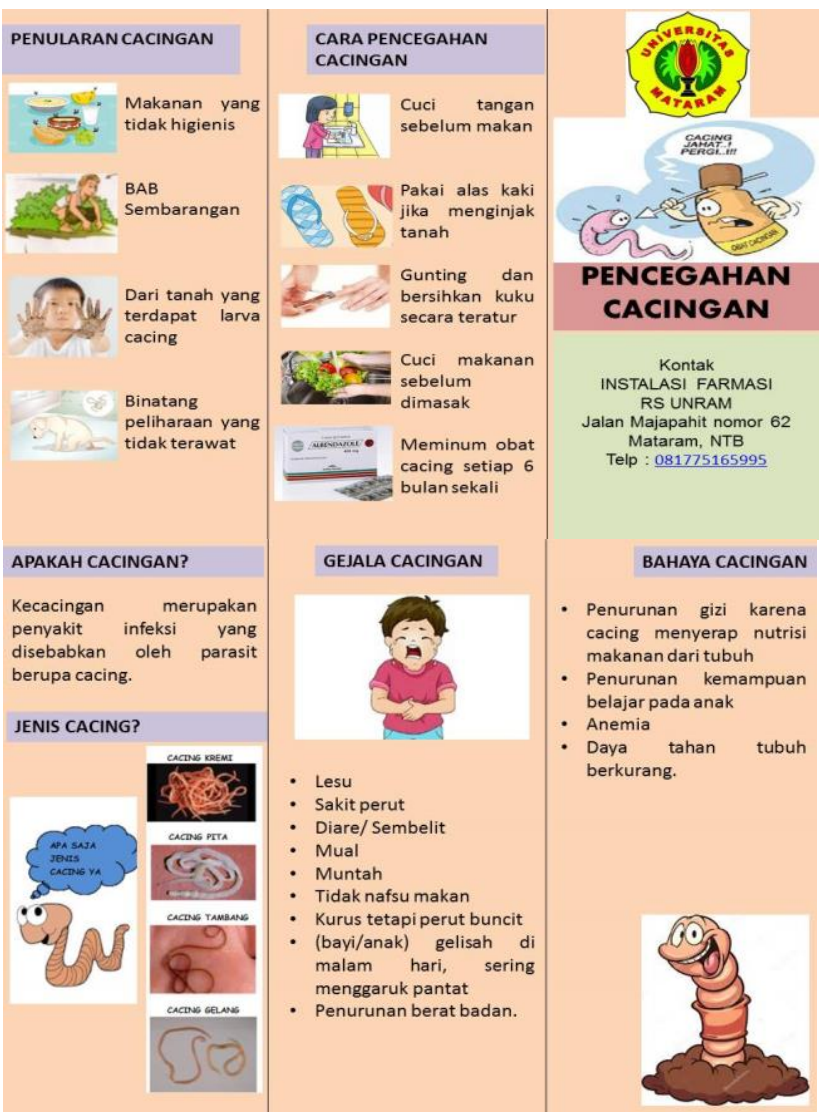

Gambar 3. Leaflet Sosialisasi Pencegahan Kecacingan
Setelah itu dilakukan uji normalitas data menggunakan Shapiro-Wilk, didapatkan data tidak terdistribusi normal. Uji beda antara nilai pre-test dan post-test dilakukan menggunakan uji Wilcoxon. Hasil uji Wilcoxon menunjukan terdapat perbedaan yang signifikan antara nilai pre-test dan post-test dengan nilai $\mathrm{p}=0.03$

Tabel 1. Perbandingan Nilai Pre-test dan Post-test Peserta Sosialisasi

\begin{tabular}{lcc}
\hline Jenis test & Nilai Rerata & P value \\
\hline Pre-test & 5,48 & \multirow{2}{*}{0.03} \\
\hline Post-test & 7,69 & \\
\hline
\end{tabular}

Sebelum mengakhiri acara dilakukan sesi foto bersama dengan peserta serta pemberian informasi untuk pengambilan obat cacing di Puskesmas Tanjung Karang pada bulan Agustus.

\section{Simpulan}

Telah dilaksanakan kegiatan sosialisasi di Desa Batu Ringgit Selatan, Kecamatan Sekarbela, Kota Mataram. Kegiatan sosialisasi diikuti oleh 30 orang. Kegiatan berjalan dengan lancar sesuai dengan rencana. Sosialisasi berhasil terlaksana dengan baik, terlihat dari peningkatan nilai rerata pre-test dan posttest.

\section{Ucapan Terima Kasih}

Terima kasih kami ucapkan sebesar-besarnya kepada pihak Puskesmas Tanjung Karang yang membantu kegiatan sosialisasi ini.

\section{Daftar Pustaka}

Anwar, R. (2014). Hubungan antara higiene perorangan dengan infeksi cacing usus (Soil Transmitted Helminths) pada siswa SDN 25 dan SDN 28 kelurahan Purus kota Padang Sumatera Barat. Padang: Universitas Andalas.

Eryani, D., Fitriangga, A., \& Kahtan, M. (2015). Hubungan personal hygiene dengan kontaminasi telur Soil Transmitted Helminths pada kuku dan tangan. Pontianak: Universitas Tanjungpura.

Ismid, I. (1999). Infeksi cacing yang ditularkan melalui tanah pada murid sekolah dasar peserta. Majalah Parasitologi Indonesia, 1-9.

Kementerian Kesehatan RI. (2006). Keputusan Menteri Kesehatan Republik Indonesia Nomor 424/MENKES/SK/VI/2006 tentang pedoman pengendalian cacingan. Jakarta: Kementerian Kesehatan Republik Indonesia. 
Kementerian Kesehatan RI. (2017). Peraturan Menteri Kesehatan Republik Indonesia Nomor 15 Tahun 2017 tentang penanggulangan cacingan. Jakarta: Kementerian Kesehatan Republik Indonesia

Kurniawan, A. (2010). Infeksi parasit: dulu dan masa kini. Majalah Kedokteran Indonesia, 487.

Margono, S. (2003). Important human helminthiasis in Indonesia. In $\mathrm{WHO}$, Controlling disease due to helminth infections (pp. 4-5). Geneva: World Health Organization.

Sutanto, I., Ismid, I. S., Sjarifuddin, P. K., \& Sungkar, S. (2008). Buku Ajar Parasitologi Kedokteran, Keempat. Jakarta: FKUI.

Weatherhead, J. E., \& Hotez, P. J. (2015). Worm Infections in Children. Pediatrics in Review, 341-354.

WHO. (2003). Controlling disease due to helminth infections. Geneva: World Health Organization. 